\title{
Chat Me Out of Here!
}

\section{Pit in the Warehouse: An Interactive Fiction Game with an Instructional Mission}

\author{
https://doi.org/10.3991/ijac.v14i2.25917
}

\author{
Dr. Cäcilie Kowald ${ }^{(凶)}$, Beate Bruns \\ time4you $\mathrm{GmbH}$, Karlsruhe, Germany \\ kowaldatime4you.de
}

\begin{abstract}
Conversational user interfaces, aka chatbots, offer new ways of interaction that can be used not only for task-led applications, but also for learning itself. From drill-and-practice assistants to digital tutors and coaches, Conversational Learning offers a variety of new and extensive options to support individuals through the learning process and to push the boundaries of classroombased learning. However, Conversational Learning applications that go beyond simple question-and-answer dialogs are still rare. "Pit in the Warehouse" takes a new stance to Conversational Learning: by combining a dialogical escape room challenge with an interactive fiction approach and compelling storytelling, it creates an engaging and low-threshold type of game-based learning.
\end{abstract}

Keywords-e-learning, digital learning, workplace learning, conversational learning, conversational experience, chatbots, artificial intelligence, AI, gamification, serious games, interactive fiction games, conversational games

\section{Background}

In marketing and service, but also in training and development, artificial intelligence-supported (AI-supported) digital assistants and chatbots are on the rise. Many digital learning apps already incorporate conversational assistants-e.g., for drill-and-practice activities in language training (Andy English Bot, Duolingo) or for (mental or physical) health self-education (Lark, Woebot, Youper). Chatbots act as virtual guides to the Louvre and the British Museum, helping people discover the museums' artworks with entertaining and instructive stories. This kind of interaction with a chatbot to learn something establishes a dialogical learning process that we call Conversational Learning. Conversational Learning offers a variety of new and extensive options to support individuals through the learning process and to push the boundaries of classroom-based training.

Just as humans use their language not only for conveying information, but also for playing games, chatbots offer room for gamification, too, from simple quizzes to complex instructional games. 


\section{The game}

Chatbot "Pit in the Warehouse" is an interactive fiction game about fundamental processes of materials management. It combines an interactive fiction approach with an escape room scenario and compelling storytelling, thus realizing a new concept of a serious game.

Target groups are trainees, students, and employees from materials management, logistics, and warehousing.

In "Pit in the Warehouse," they learn to know central processes of materials management in a playful and self-directed way during their conversations with Pit. They solve several typical tasks and, thus, demonstrate what they have learned.

At the same time, they experience the processes in context, illustrating their interdependencies and importance in real-word environments. They see how a large, international trading company operates, by the example of a coffee importer in Hamburg at the onset of the 20th century. The historic setting not only makes for compelling storytelling, but it also conveys historical background knowledge.

The game starts with Pit asking the user for help: "Oh, great that you're answering. I have no idea where I am at the moment. Just a second ago, I was on my way to coffee break with my colleagues. And now I'm suddenly here ... Do you have an idea where I am? Here is another picture ..."

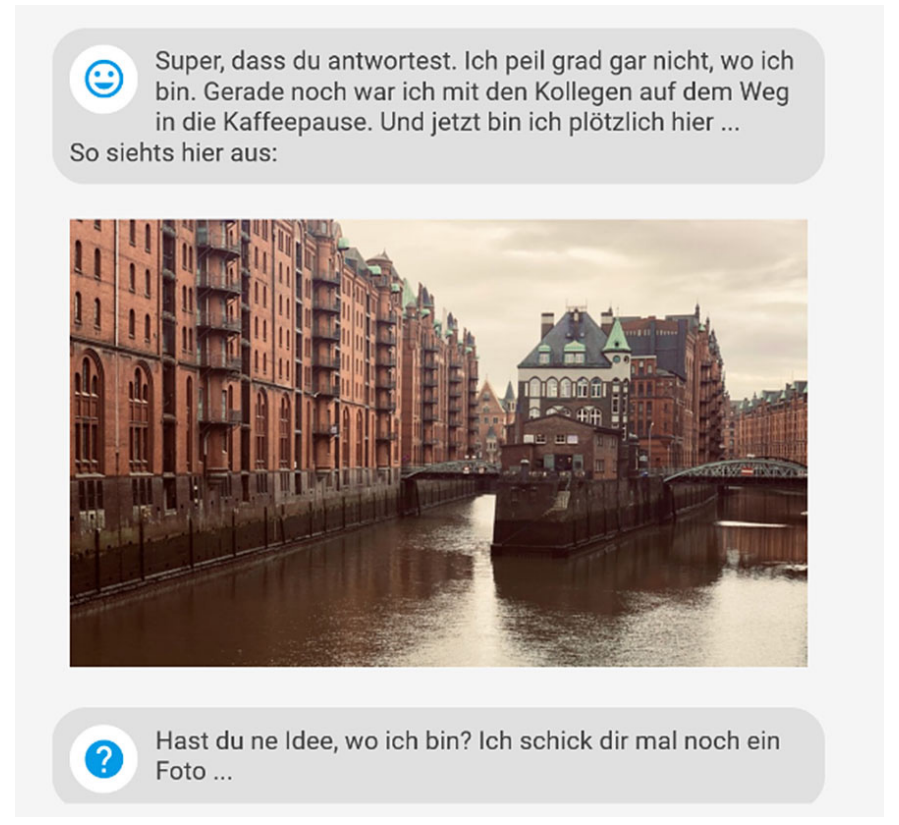

Fig. 1. Pit in the warehouse: onboarding

By and by, the story evolves, and Pit's task becomes clear. The strange, unfamiliar place where Pit has unexpectedly found himself turns out to be Hamburg during the 
early days of the 20th century. In order to get back to the present, Pit must perform an inbound-goods receiving process in accordance with materials management standards.

Pit and the user have several rooms to explore. In each room, there are items to pick up, people to talk to, information to retrieve, and sometimes a quiz or challenge to pass, in order to reach the next level of the game and gain access (or get back) to other rooms.

Examples:

At Level 1: "Hmm, this looks like an incoming goods receipt checklist. But something is wrong-just what?"

At Level 2: "Hey you, this guy here won't let me go back! I have to tell him first what needs to be entered in the goods receipt book. Help me, please!"

At Level 3: "But this is really the last task I will take ... I am supposed to correct the checklist for the incoming goods inspection!"

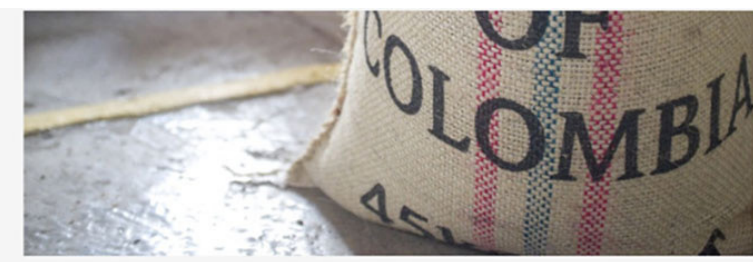

Klasse! So kommen wir wirklich gut weiter. Nun komm ich bald wieder weg hier.

Merkzettel für die Warenannahme

1. Anlieferer stellt Ware bereit

2. Prüfen, ob Empfänger korrekt

3. Preis notieren

4. Abladen

5. Lieferung unbeschädigt und vollständig?

6. Quittieren

7. In die Warenannahme bringen

8. Lieferschein mitnehmen

$\mathrm{Hmm}$, das sieht wie eine Checkliste aus. Aber irgendwas ist falsch - nur was? Ich komm nicht drauf - hast du eine Idee?
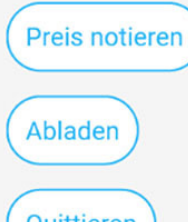

Quittieren

Fig. 2. Level 3 challenge: correct the incoming goods reception checklist

In the course of the game, Pit (together with the user) has to prove his or her knowledge about fundamental materials management processes and methods, like: 
- Receipt of incoming goods

- Random quality inspection

- Maintenance of the inspection record

- Weighing, measuring, counting

- Entry in the goods receipt book

- The 5 Rs of logistics

When all tasks are accomplished, Pit gets what he so urgently wants: to be back home. "Finally, I'm back! I'm so relieved ... I thought I'd have to count coffee bags forever ..."

But he doesn't leave without giving the user credit: "By the way: thank you for helping me!"

HOPPLA, wo bin ich denn jetzt? Eben hab ich doch noch in Hamburg Kaffee getrunken - hey, hallo, da bist du ja! Endlich bin ich zurück!

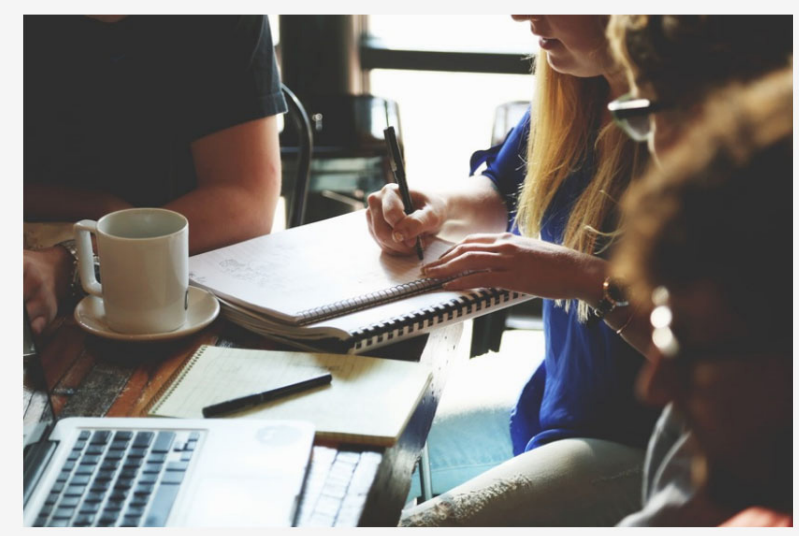

Puh, da bin ich aber erleichtert ... Dachte schon, ich muss jetzt ewig Kaffeesäcke zählen ... Übrigens: danke, dass du mir geholfen hast!.

Fig. 3. End of the game: finally back home!

\section{Dialog concept}

"Pit in the Warehouse" was designed as a simulation of a specific communicative situation with a dialog partner of a distinct character: Pit is a social, helpful guy, who now is stressed by his obscure situation and asks for help.

In "Pit in the Warehouse," it's not the chatbot's task to teach the user, but vice versa: The chatbot asks the user for help, and the user's role is to give Pit helpful knowledge to get him out of the situation. This way, the typical roles of chatbot and user are inverted: 
It's the user who is supposed to be the expert, not the chatbot. The user, therefore, takes a much more active and explorative stance than in an instructional dialog and acts from a position of competence and autonomy.

From time to time (randomly), Pit expresses his frustration and his wish to get back home ("I don"t like it here" or "I really wish I'd be back home") or he presses the user for more help ("Do you have an idea?" or "What else could we do?"). This, together with Pit's personality, gives the conversation a certain urgency and a unique human twist and, from the start, establishes a relationship between the user and the chatbot.

\section{$4 \quad$ Navigation}

The user can navigate through the game in two ways. They can either give Pit verbal commands, like "look around", "what do you see", "what can you do", "examine ..." (an item) etc. Or they can click on the text links provided in Pit's answers, giving direct access to operations on items.

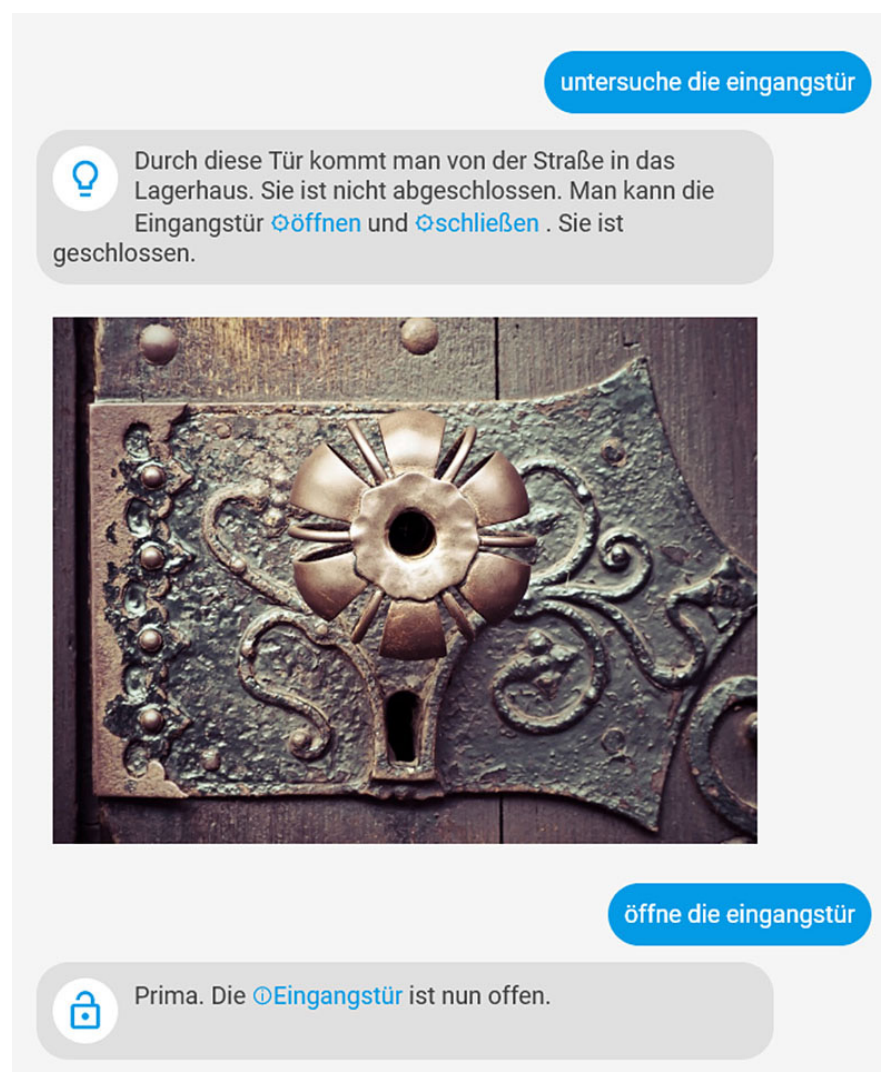

Fig. 4. Navigating through the warehouse by verbal instructions and linked commands

In situations when additional, special options are available, Pit offers buttons suggesting the next action. 
ist sicher nicht die Ostsee ... Wenn ich so überlege - es ist bestimmt Hamburg.

Hier hast du noch zwei Fotos ... Klick auf den Button zum Anschauen.

\section{Zeig das Foto der Laderampe}

Zeig das Foto der Hafenarbeiter

\section{Zeig das Foto der Laderampe}

Über diese Rampe werden die Waren direkt vom Kanal aus in das Lager geschafft. Das Tor führt direkt hinein.

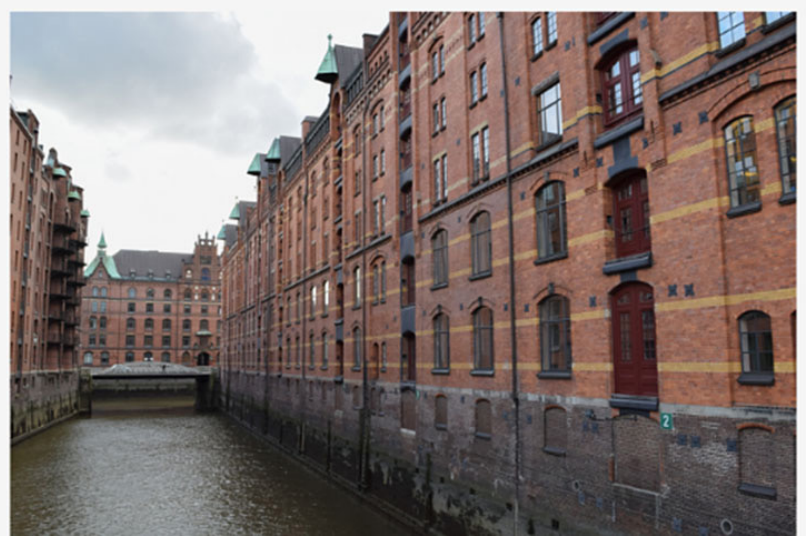

Fig. 5. Buttons showing special navigation options

To facilitate gameplay, Pit gives the most important commands and offers a full list of available commands on request ("help").

ch könnte dir Gegenstände beschreiben, mich Umsehen, dir beschreiben wo es hin geht oder was ich Dabei habe.

Außerdem kannst du jederzeit Hilfe eingeben, um diesen Text nachzulesen. Wenn du es ganz genau wissen willst, kann ich dir auch eine Liste der wichtigsten funktionierenden Befehle anzeigen.

Sag mir einfach was ich tun soll.

Fig. 6. Navigation/Dialog help 


\section{The technology: Jix}

"Pit in the Warehouse" was developed with Jix [1], an AI solution by time4you $\mathrm{GmbH}$ [2] designed specifically for developing and running Conversational Learning applications. The application can be used as a cloud service, or on-premises, by browser or iFrame.

Jix combines an intelligent bot with a straightforward and clear script language, Liza script. Liza script is easy to learn yet very elegant and powerful, making it possible to create subject-specific chatbots and virtual assistants based on media didactics and actual organizational needs, regardless of use-case, industry, or subject-matter. It takes only a very short training period because Liza script is so simple, easy to understand, and manageable, providing an authoring tool that is quick and easy to use, even without a background in IT development. At the same time, pedagogical applications are made easy with the many options provided by Jix for designing outputs (buttons, menus, etc.) and for integrating different media (audio, image, video, links on websites, and applications). Thus, Jix is a very useful tool for media didactics professionals and for learning content designers, enabling authors to easily create very effective learnbots in a short period of time, without having to engage external developers, programmers, or agencies.

"Pit in the Warehouse" can be easily adapted to specific requirements of a customer-e.g., by adapting contents, tasks, and quizzes or by changing the story's time, environment and persona. The language (currently German) is also customizable, as are the look and feel (logo, type, colors, images, icons).

In addition, "Pit in the Warehouse" can be integrated into any SCORM LMS as a SCORM package.

\section{Conclusions}

"Pit in the Warehouse" shows how chatbots can be used for gamification in an engaging way that is not only instructive, but also fun - and relatively easy to implement. Scripting the chatbot takes only a fraction of the time needed for programming an escape room video game. Of course, the overall game design is decisive for learning success, as are the design of the tasks and riddles - but that's the case in every escape room game, whether realized as a chatbot/interactive fiction or in video programming. However, if a riddle turns out to be too difficult, the chatbot can be adapted much more easily than a video game: you just change a dialog turn, give the user one more hint or make a hint more obvious - a task of a few minutes instead of a programmer's day of work.

The chatbot's personality and contributions to the dialog play important roles for the overall appeal of the game; they involve the user with the story and establish a relationship between the user and the chatbot.

Storytelling, of course, also makes a difference. "Pit in the Warehouse" does not (as would seem natural) play in a modern business world, but in a historical setting. This not only allows the game to convey background information on historical trades, but it also gives the game additional charm and attraction. 
"Pit in the Warehouse" is an example of how a more creative, conversational approach to chatbot design gives way to completely new, engaging application scenarios, beyond question-answering virtual assistants or instructional digital tutors.

\section{$7 \quad$ References}

[1] www.jix.ai

[2] www.time4you.de

\section{Authors}

Dr. Cäcilie Kowald is a learning designer and consultant at time4you $\mathrm{GmbH}$ in Karlsruhe, Germany. With an academic background in mathematics and literature, she worked as a consultant, copywriter, and concept designer in corporate communications for many years, with a focus on complex products and IT.

Beate Bruns, M.A., is a founder and managing partner of time4you $\mathrm{GmbH}$ communication \& learning in Karlsruhe, Germany. As a consultant, she supports organizations to successfully integrate new IT technologies in their learning, training, and information management processes. She is an author of several scientific publications on learning, HR, and workplace digitalization. E-mail: bruns@time4you.de

Article submitted 2021-08-02. Resubmitted 2021-09-20. Final acceptance 2021-09-23. Final version published as submitted by the authors. 